Article

\title{
Economic Globalization Impacts on the Ecological Environment of Inland Developing Countries: A Case Study of Laos from the Perspective of the Land Use/Cover Change
}

\author{
Jun Wang ${ }^{1}$, Lichun Sui ${ }^{1}$, Xiaomei Yang ${ }^{2,3,4}$, Zhihua Wang ${ }^{2,3, *} \mathbb{D}$, Dazhuan Ge ${ }^{4,5, *}$, \\ Junmei Kang ${ }^{1}$, Fengshuo Yang ${ }^{2,3}$, Yueming Liu ${ }^{2,3}$ and Bin Liu ${ }^{2,3}$ \\ 1 College of Geological Engineering and Geomatics, Chang'an University, Xi'an 710054, China \\ 2 State Key Laboratory of Resources and Environment Information System, Institute of Geographic Sciences \\ and Natural Resources Research, CAS, Beijing 100101, China \\ 3 College of Resources and Environment, University of Chinese Academy of Sciences, Beijing 100049, China \\ 4 Jiangsu Center for Collaborative Innovation in Geographical Information Resource Development and \\ Application, Nanjing 210023, China \\ 5 College of Geography, Nanjing Normal University, Nanjing 210023, China \\ * $\quad$ Correspondence: zhwang@lreis.ac.cn (Z.W.); gedz@njnu.edu.cn (D.G.); Tel.: +86-10-6488-8955 (Z.W.)
}

Received: 25 June 2019; Accepted: 13 July 2019; Published: 19 July 2019

check for updates

\begin{abstract}
Economic globalization promotes the economic development of underdeveloped regions but also influences the ecological environments of these regions, such as natural forest degradation. For inland developing regions with underdeveloped traffic routes, are the effects on the ecological environment also as obvious? To reveal the response characteristics of the ecological environment of the inland developing countries to globalization, we took Laos as an example, and used the land use/cover change data and also its exports and imports data to analyze the ecological environment change since the millennium. Land use transfer matrix analysis showed that Laos had encountered a large conversion of $14.43 \%$ natural forest to plantation forest since 2000 to 2017, and also a degradation of $5.94 \%$ natural forest to shrubland and grassland. Landscape pattern analysis showed that these changes were the main reasons of the fragmentation of ecological patches, which would lead to a reduction in biodiversity. More, topographic analysis further showed that natural forest degradation mainly took place in high-altitude and large slope areas, which could increase the potential of natural hazards such as floods. Coupling analysis with its exports and imports data indicated that economic globalization still had a significant impact on the country's ecological environment although Laos is an inland developing country. Laos should strengthen the regulation of renewable resources such as forests and water resources, to avoid losing the renewable resources market while still enjoying the dividends of economic globalization. At the same time, it is necessary to accurately evaluate the indirect impacts of development on neighboring countries to ensure sustainable development.
\end{abstract}

Keywords: economic globalization; ecological environment; land use/cover; landscape pattern; topographic analysis

\section{Introduction}

Land use/cover change (LUCC) is a common tool to represent the interaction between human activities and the natural environment [1-3]. LUCC is a critical factor in landscape patterns and ecosystem services [4-8]. The growth of the world economy has traditionally relied on the consumption of non-renewable resources. Take forest resources as an example. Economic development can promote 
deforestation, affecting the value and benefits of ecosystem services [9], and this loss of ecological function can pose other challenges to the environment. It is true that economic globalization has promoted the effective allocation of global resources and improved the utilization of environmental resources through international trade. However, the environmental protection standards of developing countries are often more relaxed than those of developed countries, attracting the transfer of low-value and high-pollution enterprises into developing countries. Frequent international trade has also increased the probability of cross-border pollution incidents [10,11]. Economic globalization has become a powerful factor that fundamentally changes global land use/cover landscape patterns, increasing the complexity of land use/cover landscape patterns and dynamic evolution, which in turn, has a profound impact on the structure, function, and evolution of ecosystems [12-14]. Problems, such as surface runoff and soil erosion [15,16], variations in soil properties [17,18], water pollution [19], and biodiversity loss [20] are generated. Given the rapid rate of change and the potential impacts, it is meaningful to determine the response of the ecological environment of developing countries in the context of economic globalization. This can help governments alleviate conflicts between economic development and protection of the ecological environment, allowing for the attainment of sustainable development goals [21,22].

Many studies have used LUCC to study changes in the ecological environment in the context of globalization. Lambin et al. [23] studied how to protect forest systems and improve food production during economic globalization, drawing on examples from several developing countries. It was suggested that policies designed to coordinate development with nature conservation need to make land change a part of the earth system. Rutten et al. [24] used Vietnam as an example of an export-oriented country, and compared different land use/cover results in different regions after having taken the global and local trade links into account. They discovered the environmental problems caused mainly by globalization, including economic policies that stimulate growth and urbanization that may work at the expense of forest lands, and lead to greater greenhouse gas emissions from the landscape. Yamamoto et al. [25] used Indonesia as an example, and found that the reduction of forest land will cause a decline in agricultural production. They surmised that the loss of forested land will completely offset the gains from the expansion of cultivated land, and ultimately result in a decline in overall income. In contrast, Paudyal et al. [26] explored the impact of land use change on ecosystem supply and social benefits over the past 40 years in the Phewa watershed in western Nepal, and discovered that the degradation of agriculture and grasslands has led to a restoration of the dense forest ecosystem. Meyfroidt et al. [27] pointed out that linking land use/cover to globalization processes can help us better understand land change, trade, policies, and other potential drivers. Destek et al. [28] investigated the impact of different levels of globalization (i.e., economic, social, and political globalization) on carbon emissions in central and eastern European countries between 1995 and 2015, and concluded that economic globalization has increased carbon emissions. However, all of the above studies on the impact of globalization on the ecological environment are mostly focused on developed countries [28] or developing countries with developed marine traffic [24]; few inland developing countries with underdeveloped transportation have been studied. We might intuit that inland countries with underdeveloped traffic are hardly affected by globalization, but is this actually the case? If they are affected, what are the main impacts of the ecological environment? What is the extent of these effects, and how could we control them? The answers to these questions are of high value for determining whether inland developing countries should actively respond to the ecological environmental problems brought about by globalization, and how best to do so.

Laos is located in the Mekong River Basin, has a high forest cover, and is rich in mineral [29] and water resources [30]. Although Laos borders many coastal countries, it is the only inland country in southeast Asia, and one of the poorest countries in the Association of Southeast Asian Nations (ASEAN). At a meeting of the General Council of the World Trade Organization held in Geneva, Switzerland on 26 October 2012, Laos was officially approved to join the World Trade Organization (WTO), becoming the 158th member country, and the last remaining member of ASEAN to join the 
WTO [31]. Joining the WTO has brought economic development opportunities for Laos, enabling Laos to fully enjoy the preferential foreign trade tariff policies between members of the WTO, which greatly promotes the development of Laos' foreign trade. According to the World Bank Data, Laos has maintained a GDP growth rate of more than $6 \%$ since 2003 [32]. The consumption of ecological resources required for such rapid economic growth will inevitably lead to impacts on the ecological environment, especially the LUCC of forest, cropland, and water.

Kokmila et al. [33] used Geographic Information System (GIS) technology to analyze the status of forest resources and soil erosion in Laos, and proposed some countermeasures to maintain soil and water and prevent forest shrinkage. Hewanma et al. [34] used the Lorenz curve and the Gini coefficient to characterize and quantify the change of forest cover in Laos based on status data in 1982/1992 and 2002. That study found that the forest cover in Laos showed a downward trend, and its main driving force was poverty and farming activities such as land clearing. Fujisaka [35] investigated the current environmental problems associated with rice cultivation in Laos, and pointed out that the forest ecosystems in Laos were degraded by logging, burning, and rice monoculture. They concluded that the potential for restoring the environment through natural succession was negligible. Sandewall et al. [36] explored how the Laotian government worked with local residents to achieve sustainable uses of forest land, and pointed out that changes in land use/cover patterns were related to forest land allocation, infrastructure construction, and new economic policies implemented in the region. However, the existing research on ecological and environmental issues mainly focused on a single aspect, such as forests or cropland, and lack an analysis of the driving force of globalization. Determining the impact of globalization on Laos's ecological environment is of great value to the government for creating policies that maintain an ecologically-sustainable version of economic development in the context of globalization.

Here, we used Laos as a model system to explore the effects of changing ecological environment patterns in an inland developing country in the context of economic globalization via a coupled analysis of land use/cover change data and global data. Our main work and innovations are: (1) using remote sensing time series land use/cover data and transfer matrix to detect trends in LUCC. This work can locate the major change land cover types, and provide directions for the follow-up analysis of ecological environmental impact; (2) analysis of changes in ecological environment quality using principles of landscape ecology. Here we use landscape index to quantitatively analyze LUCC to further analyze the potential impacts of LUCC on ecological environment, such as biodiversity; (3) analysis of potential ecological environmental risks in LUCC areas using GIS topographic overlays. By using slope and elevation to analyze the distribution of land cover change, we can further analyze the LUCC impacts on ecological problems such as the soil and water conservation; and (4) a combination of import and export data to analyze the contribution of globalization to the ecological changes observed in Laos. This analysis is a critical step to reveal the relationship between economic globalization and the ecological environment, and then provide beneficial references for ecological environment management. The results of the research presented in this paper can provide guidelines for the optimal allocation of land resources for the sustainable development of Laos in the context of globalization. In addition, this study can provide a reference for multilateral cooperation within the ASEAN Free Trade Area, for countries along the Belt and Road Initiative, and other inland developing countries needing to understand and respond to the ecological problems brought about by globalization.

The structure of this paper is organized as follows. Section 1 mainly describes the impact of economic globalization on ecological environment through LUCC, and the targets of this study. Section 2 introduces the study area and data sources study. Section 3 details the methods used in this study, including land use transfer matrix, landscape index and topographic analysis. Section 4 describes the results of by the methods. Section 5 combines economic data to conduct a coupling analysis of land use change results. Conclusions are drawn in last Section 6. 


\section{Study Area and Data Source}

\subsection{Study Area}

Laos, which is an inland country located in the northern part of the Indo-Chinese peninsula (between $100^{\circ} 05^{\prime}-107^{\circ} 38^{\prime} \mathrm{E}$ and $13^{\circ} 54^{\prime}-22^{\circ} 30^{\prime} \mathrm{N}$ ), has an area of $236,800 \mathrm{~km}^{2}$. Laos is bordered by the western Yunnan Plateau (Yunnan, China) to the north, by Vietnam to the east, by Thailand to the west, by Myanmar to the northwest, and by Cambodia to the south (Figure 1). Laos is connected by the Mekong River, Asia's most important transnational water system. It is the only inland country in southeast Asia and has an important impact on the biodiversity, biogeochemical cycles, and ecosystem productivity on the Mekong River Basin. The country is divided into three parts (Figure 1): northern Laos, central Laos, and southern Laos. Laos is high in the north and low in the south, with an altitude of $500 \mathrm{~m}-2800 \mathrm{~m}$. Laos has a tropical and subtropical monsoon climate, with a dry season (November-April) and a rainy season (May-October). During the rainy season, the average temperature is $24.2{ }^{\circ} \mathrm{C}$, the average annual rainfall is about $1700 \mathrm{~mm}$, and the rainfall on the plateau and mountains is about $1300 \mathrm{~mm}$. During the dry season, the average temperature is $27.3^{\circ} \mathrm{C}$ and there is almost no rainfall due to the dry, cool northeast wind. The industrial foundation of Laos is weak. Wood processing, rice milling, and tin mining are the main types of industry. The main crops of Laos include rice, coffee, tobacco, and cotton.

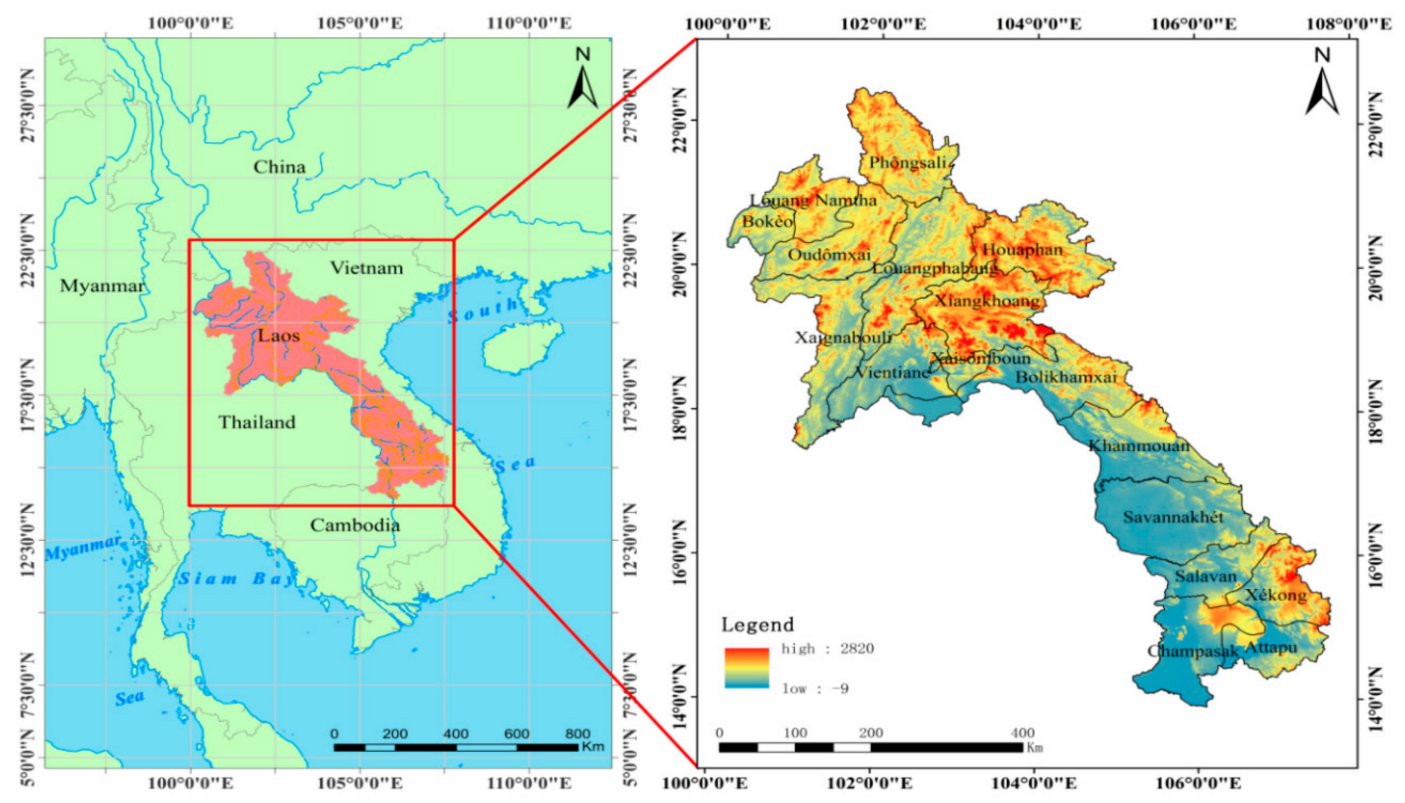

Figure 1. Position and digital elevation model (DEM) of the study area.

\subsection{Data Source}

With the development of remote sensing, GIS, and other technologies, global and regional land cover products based on remote sensing images have been successfully released. Currently, there are more than 20 sets of land cover products [37]. Widely used are the IGBP DISCOVER land cover data produced by the US Geological Survey [38], GLC2000 Land Cover Data produced by the Joint Research Centre of the European Union [39], MODIS Land Cover Data produced by Boston University [40], GLOBCOVER land cover data produced by the European Space Agency [41,42], Globe Land30 Land Cover Data produced by China National Basic Geographic Information Center [43], FROM-GLC land cover data produced by Tsinghua University [44], and SERVIR MEKONG regional land cover data jointly produced by teams such as USAID, NASA, and ADPC (https://rlcms-servir.adpc.net/en/landcover/). Since the existing land cover products have different classification systems, classification methods, production processes, spatial resolutions, etc. [45-47], they will produce very different products when applied to regional scale or global scale research [48]. 
Considering that the SERVIR MEKONG data is specifically for the Mekong River Basin including Laos, it had several advantages for this research, mainly including: (1) the data is classified using the Landsat TM/ETM+ data source with a spatial resolution of up to $30 \mathrm{~m}$; (2) it includes data from 1987 to 2017 with an annual cycle; (3) it distinguishes human activity land use from nature land use systems, such as the plantations, mining areas, and aquaculture; and (4) data producers are familiar with the Laos region, such as the Asian Disaster Preparedness Center (ADPC) and the International Centre for Integrated Mountain Development (ICIMOD), which are critical to the accuracy assurance of the data products. Since the purpose of this study was to explore the land use changes with the background of globalization, we selected four data periods from 2000 to 2017 in 5-year cycles for analysis and merged some land use/cover types with similar ecological and environmental impacts. The final 11 types of land use/cover types are: Water, Natural Forest (Deciduous Forest, Evergreen Broadleaf, Mixed Forest), Plantation Forest, Built Up, Cropland, Mining, Barren, Wetlands, Grassland, Shrubland, and Aquaculture (Table 1).

Table 1. Correspondence and merging of codes between SERVIR MEKONG2010 classification systems.

\begin{tabular}{cccc}
\hline Code & Servir Mekong 2010 & Merge Type & Abbreviations \\
\hline 0 & Unknown & - & - \\
1 & Surface Water & Water & WT \\
2 & Snow and Ice & - & - \\
3 & Mangrove & - & - \\
4 & Flooded Forest & - & - \\
5 & Deciduous Forest & Natural Forest & NF \\
6 & Orchard or Plantation Forest & Plantation Forest & NF \\
7 & Evergreen Broadleaf & Natural Forest & NF \\
8 & Mixed Forest & Natural Forest & BU \\
9 & Urban and Built Up & Built Up & CL \\
10 & Cropland & Cropland & - \\
11 & Rice & - & MI \\
12 & Mining & Mining & BR \\
13 & Barren & Barren & WL \\
14 & Wetlands & Wetlands & GL \\
15 & Grassland & Grassland & SL \\
17 & Shrubland & Shrubland & AL \\
\hline
\end{tabular}

To further analyze the potential environmental problems caused by LUCC, we collected the elevation data for the Laos region from the Geospatial Data Cloud (http://www.gscloud.cn/) with a spatial resolution of $90 \mathrm{~m}$. Slope information was further generated in ArcGIS 10.2. In order to explore this change in land use and drive the analysis of the effect of economic globalization, we also collected agricultural and industrial data from the World Bank's public data website(https: //data.worldbank.org.cn/) and the import and export website (https://resourcetrade.earth/data?year= $2017 \&$ exporter $=418 \&$ category $=5 \&$ units $=$ value $)$.

\section{Methods}

We used three methods to analyze the temporal and spatial characteristics of LUCC in Laos, which are a land use transfer matrix [49], a landscape pattern index, and a topographic overlap analysis. The land use transfer matrix identified the intensity and direction of the conversion between various land uses, so that the quantity and structural characteristics of the LUCC during the study period could be analyzed. We used the remote sensing analysis software ENVI 5.3 to implement the LUCC transfer matrix calculation for the study area.

Pattern determines function, and function counteracts pattern [50]. We used landscape pattern analysis as an indication of the quality of the ecological environment, especially the species diversity. 
We used the landscape pattern index to quantitatively assess the changes of LUCC in Fragstats 4.3, and then quantitatively analyzed the ecological environment. According to the landscape index indication of the ecological environment and also the correlation between them, we selected the following four indexes:

(1) Number of patches (NP).

Number of patches (NP) was equal to the total number of patches of a patch type in the landscape at the type level, equal to the total number of all patches in the landscape at the landscape level. NP reflects the spatial pattern of the landscape and has often been used to describe the heterogeneity of the landscape. The value of the NP was also positively correlated with the fragmentation of the landscape. The general rule was that if the NP was large, the fragmentation was high. NP affects many ecological processes, such as determining the spatial distribution characteristics of various species in the landscape and changing the stability of interactions between species and synergistic symbiosis. Moreover, NP has an important influence on the spread of various disturbances in the landscape. For example, when the number of some types of patches (such as bare land) is relatively large and scattered, it may inhibit the spread of certain disturbances (such as insects and fires). The formula was as follows:

$$
\mathrm{NP}=\mathrm{N}_{i}
$$

where NP is the number of patches for landscape $i$ and $N_{i}$ is the number of patches for landscape $i$. Value range: $\mathrm{NP} \geq 1$.

(2) Mean patch size (MPS).

In general, the species diversity of a patch increases as the area of the patch increases. The average patch area represents an average condition and reflects two aspects in the analysis of landscape structure. The mean patch size (MPS) value distribution interval had a restrictive effect on the range of images or maps, which impacted the selection of the smallest patch size in the landscape. MPS indicated the degree of fragmentation of the landscape. At the landscape level, a landscape with a smaller MPS was more broken up than a landscape with a larger MPS. And at the patch level, a patch type with a smaller MPS value was more fragmented than a patch type with a larger MPS value. Our study found that changes in MPS values could impart more abundant landscape ecological information, which is the key to reflecting landscape heterogeneity. The formula was as follows:

$$
M P S=\frac{A}{N} 10^{-6}
$$

where $A$ represents the total area of all patches in the landscape (square meters), where $N$ is the total number of patches, multiplied by $10^{-6}$ to convert to units of square kilometers. Value range: MPS $>0$, no upper limit.

(3) Landscape shape index (LSI).

Landscape shape index (LSI) measured the complexity by calculating the degree of deviation between the shape and the circle or square of the same area. Compact patches (usually had a small LSI) had a small proportion of edges per unit area, which was good for saving energy, nutrients, and living things; the loose shape facilitated the interaction between the interior of the patch and the external environment, especially the exchange of energy, matter and biology. The formula was as follows:

$$
L S I=\frac{0.25 E}{\sqrt{A}}
$$

where $E$ is the total length (in meters) of all patch boundaries in the landscape, $A$ is the total area of the landscape (square meters), and 0.25 is the square correction constant. In the raster data, $E$ is the total 
number of pixels at the boundary of a certain type of map, and $A$ is the total number of pixels of a certain type. When there is only one square patch in the landscape, LSI $=1$; when the shape of the patch in the landscape is irregular or deviates from the square, the LSI value increases. Value range: LSI $\geq 1$, no upper limit.

\section{(4) Contagion index (CONT).}

The aggregation index reflected the degree of non-randomness or aggregation of different patch types in the landscape. If a landscape was dominated by a few large patches or the same type of patch was highly connected, the value of the degree of aggregation was greater. The aggregation index explicitly considers the adjacent relationship between patch types and thus reflects the spatial configuration characteristics of the landscape components:

$$
\text { CONT }=\left[1+\sum_{i=1}^{m} \sum_{j=1}^{n} \frac{P_{i j} \ln \left[P_{i j}\right]}{2 \ln [m]}\right](100)
$$

where $m$ is the total number of patch types, and $P_{i j}$ is the probability of two adjacent raster cell data types $i$ and $j$ randomly selected. The aggregation index usually measures the degree of aggregation of the same type of patch, but its value was also affected by the total number of types and their uniformity. Value range: $0<\mathrm{CONT}<100$.

The Laos region has an altitude of hundreds of meters to several kilometers. The height difference is large and the terrain is undulating. It forms a rich variety of landforms such as plains, hills, mountains, and basins. The climate difference is significant in the vertical direction. To carry out topographical overlay analysis with the land use types in the local changing areas, this paper refers to Peng's [51] elevation grading standards for the Savannakhet area in Laos, and connected these with the actual terrain of Laos, and divided the Lao region into five levels (Table 2).

Table 2. Division of elevation and slope data.

\begin{tabular}{cccccc}
\hline Grade & $\mathbf{1}$ & $\mathbf{2}$ & $\mathbf{3}$ & $\mathbf{4}$ & $\mathbf{5}$ \\
\hline Elevation & $<500 \mathrm{~m}$ & $500-1000 \mathrm{~m}$ & $1000-1500 \mathrm{~m}$ & $1500-2000 \mathrm{~m}$ & $>2000 \mathrm{~m}$ \\
Slope & $<3^{\circ}$ & $3^{\circ}-10^{\circ}$ & $10^{\circ}-35^{\circ}$ & $35^{\circ}-65^{\circ}$ & $\geq 65^{\circ}$ \\
\hline
\end{tabular}

The slope has an important influence on the ecological environment parameters, such as temperature, evaporation, precipitation, and surface runoff. A very typical example was soil erosion caused by sloping farmland. In this study, we refer to Kokmila et al. [33], and first used the DEM to generate slope data, then divided the changing area into five grades according to the slope size (Table 2), and finally analyzed the potential ecological environmental problems.

\section{Results}

\subsection{Analysis of Land Use/Cover Change}

The spatial distribution maps of land use classification in Laos from 2000 to 2017 are shown in Figure 2. The corresponding statistical data of various types are presented in Table 3 . The results of the land use transfer matrix in 2000-2017 are presented in Table 4. It can be seen from Table 3 that in 2000, the total area of natural forests in Laos was $114,087.51 \mathrm{~km}^{2}$, which was the largest land cover area, accounting for $71.40 \%$ of the total landscape. However, this area decreased at an average annual rate of $1.24 \%$. As of 2017, the natural forest area was only $129,366.03 \mathrm{~km}^{2}$, accounting for $56.29 \%$ of Laos. The largest reduction occurred from 2000 to 2005, with an annual reduction percentage of $1.99 \%$. Combined with the land use transfer matrix from 2000 to 2017 in Table 4, we can determine that the $34,721.28 \mathrm{~km}^{2}$ of reduced natural forest was mainly converted into plantation forest, grassland, cropland, shrubland, 
and water, of which plantation forest was the main transition type, accounting for $63.44 \%$ of the total reduction area.
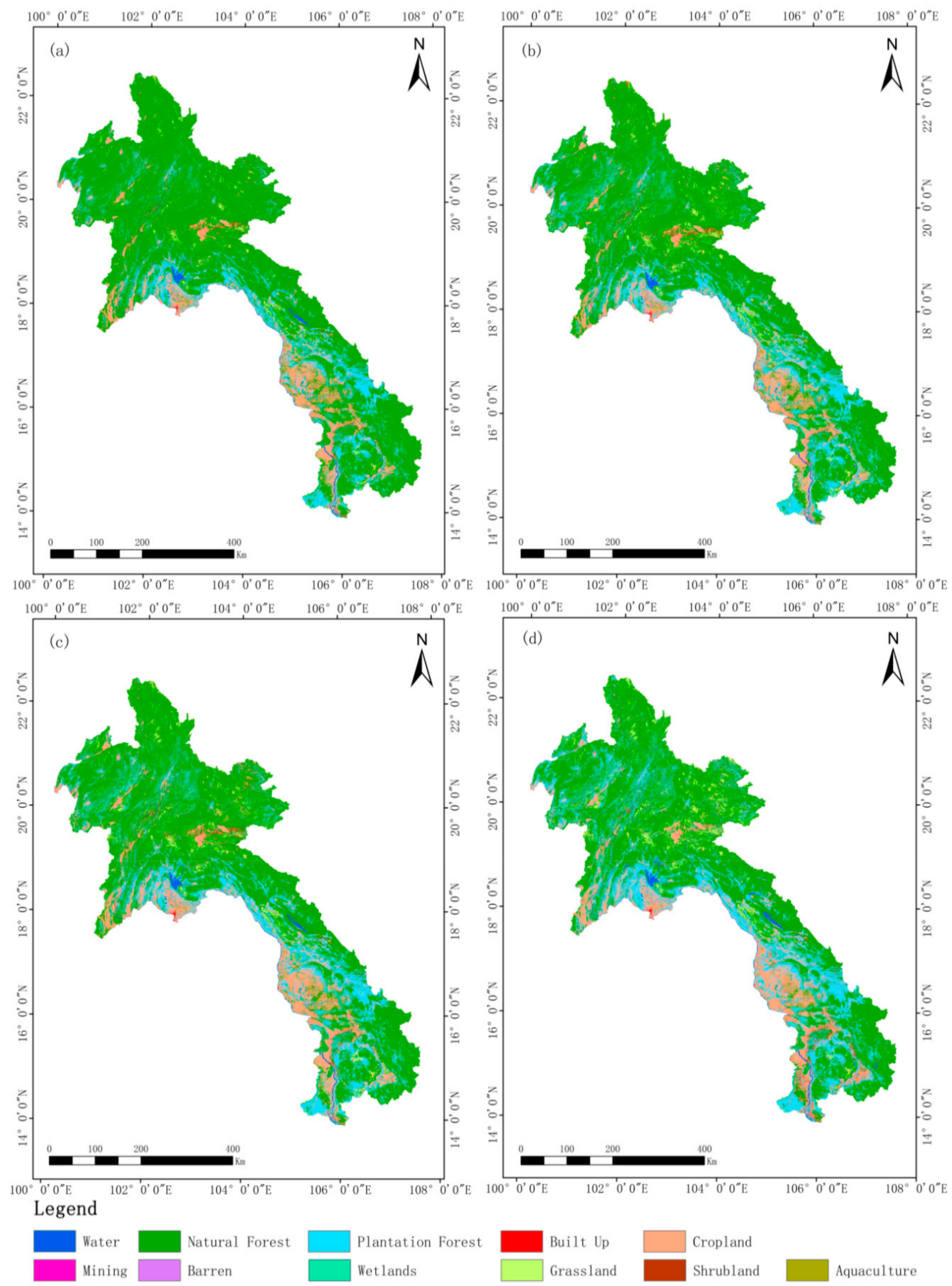

Figure 2. Land use/cover map of Laos by year: (a) 2000, (b) 2005, (c) 2010, and (d) 2017. 
Table 3. Area and percentage of different land use types in Laos, 2000-2017.

\begin{tabular}{|c|c|c|c|c|c|c|c|c|}
\hline \multirow{2}{*}{$\begin{array}{c}\text { Land Use } \\
\text { Class }\end{array}$} & \multicolumn{2}{|c|}{2000} & \multicolumn{2}{|c|}{2005} & \multicolumn{2}{|c|}{2010} & \multicolumn{2}{|c|}{2017} \\
\hline & Area $/ \mathrm{km}^{2}$ & Proportion/\% & Area $/ \mathrm{km}^{2}$ & Proportion/\% & Area $/ \mathrm{km}^{2}$ & Proportion/\% & Area $/ \mathrm{km}^{2}$ & Proportion/\% \\
\hline WT & 2903.06 & 1.26 & 2769.79 & 1.20 & 3228.77 & 1.40 & 3434.70 & 1.49 \\
\hline NF & $164,087.51$ & 71.40 & $147,753.80$ & 64.29 & $140,525.98$ & 61.14 & $129,366.03$ & 56.29 \\
\hline $\mathrm{PF}$ & $34,916.23$ & 15.19 & $44,968.45$ & 19.57 & $46,972.23$ & 20.44 & $56,911.65$ & 24.76 \\
\hline $\mathrm{BU}$ & 286.57 & 0.12 & 373.44 & 0.16 & 517.42 & 0.23 & 652.53 & 0.28 \\
\hline $\mathrm{CL}$ & $21,117.27$ & 9.19 & $22,086.52$ & 9.61 & $24,938.18$ & 10.85 & $23,156.40$ & 10.08 \\
\hline MI & 12.18 & 0.01 & 12.31 & 0.01 & 12.40 & 0.01 & 12.41 & 0.01 \\
\hline $\mathrm{BR}$ & 21.76 & 0.01 & 28.13 & 0.01 & 36.93 & 0.02 & 58.92 & 0.03 \\
\hline WL & 512.16 & 0.22 & 462.87 & 0.20 & 481.81 & 0.21 & 436.40 & 0.19 \\
\hline GL & 4875.23 & 2.12 & 9481.21 & 4.13 & $10,485.24$ & 4.56 & $12,147.91$ & 5.29 \\
\hline SL & 1086.80 & 0.47 & 1869.29 & 0.81 & 2580.26 & 1.12 & 3563.05 & 1.55 \\
\hline $\mathrm{AL}$ & 7.85 & 0.01 & 20.81 & 0.01 & 47.40 & 0.02 & 86.62 & 0.03 \\
\hline
\end{tabular}

Table 4. Land use transfer matrix in Laos from 2000 to 2017, units of $\mathrm{km}^{2}$.

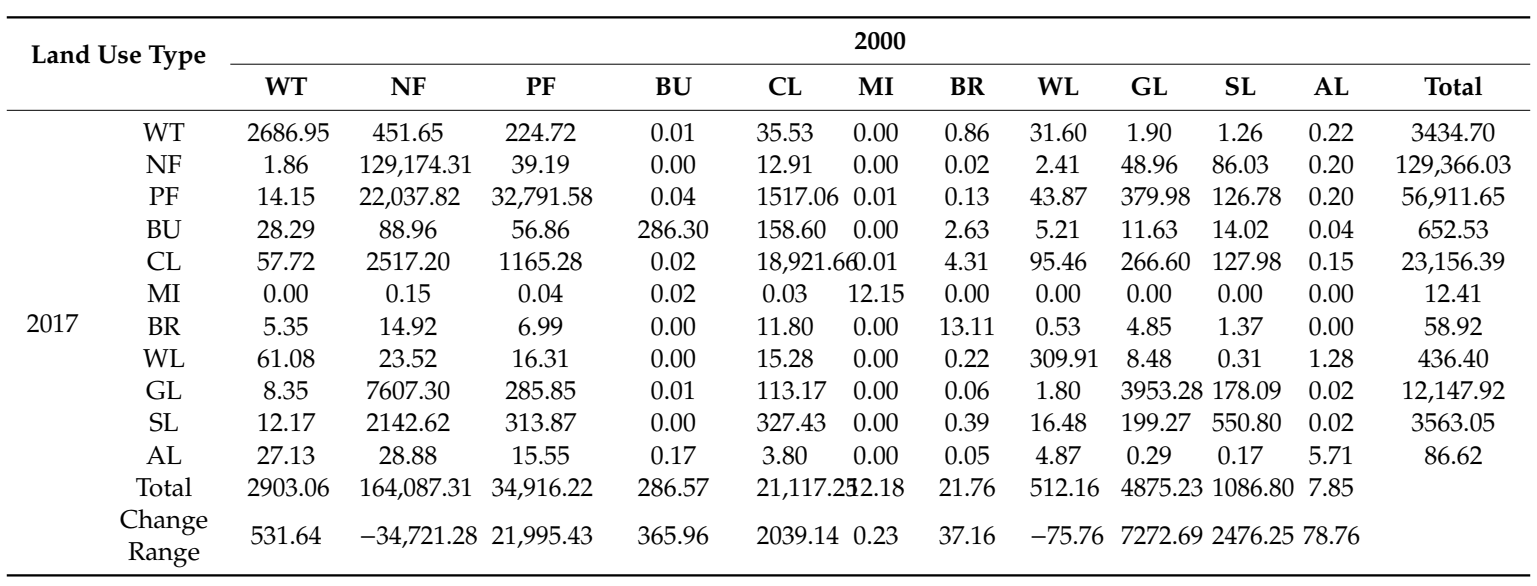

In 2000, plantation forests were the second largest land area in Laos, reaching $15.19 \%$, and grew at an average annual rate of $3.70 \%$, accounting for $24.76 \%$ of the total land area in 2017 . Combined with Table 4, we determined that natural forests were the major source of new increased plantation forests (accounting for $91.47 \%$ of the total increased area); other sources are cropland, grassland, and shrubland, of which the greatest area converted was from cropland with $1517.06 \mathrm{~km}^{2}$, accounting for the $6.30 \%$ of total increased area.

If plantations and natural forests were regarded as one forest type from the prospective of land cover, then according to Table 3, the total area of forest land (including plantation and natural forests) was $199,003.70 \mathrm{~km}^{2}$, accounting for $86.59 \%$ of the total area of Laos. Although the area decreased by 2017 , the reduction rate in the total area of Laos was much less than that of natural forests. Over the 17 years, the area of forested land in Laos was indeed decreased, especially in the case of a large loss of natural forests $\left(34,721.28 \mathrm{~km}^{2}\right)$, while the increases have been very limited (only $191.58 \mathrm{~km}^{2}$ ). Combined with the forest land conversion map (Figure 3a), we determined that the area where natural forests are converted into plantations (yellow areas) were mainly concentrated in the northern and southern areas of Laos. The conversion of natural and plantation forests to other land types (red areas) were mainly concentrated in the Oudomxai, Louangphabang, Xiangkhoang, Houaphan, and Apptapu provinces. 

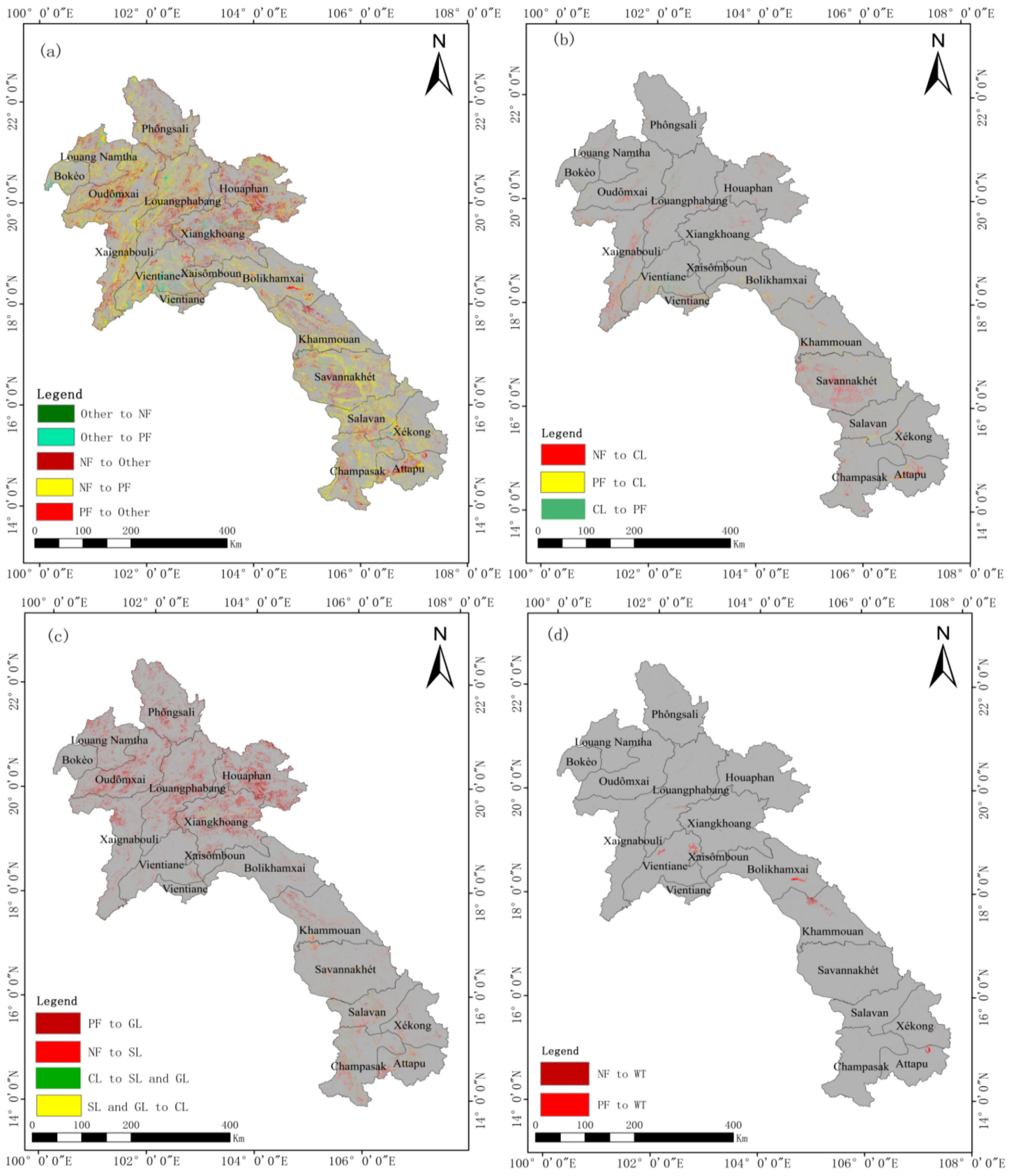

Figure 3. Land use transfer result map: (a) forest land transfer map, (b) cropland transfer map, (c) shrubland and grassland transfer map, and (d) water transfer map.

Cropland was the second-largest land use type in Laos after forested land. In 2000, the area was $21,117.27 \mathrm{~km}^{2}$, accounting for $9.19 \%$ of the entire area of Laos. Subsequently, cropland area increased first and then decreased, but in 2017 compared with 2000, cropland increased by $2309.14 \mathrm{~km}^{2}$. According to the transfer matrix in Table 4, cropland was mainly converted to plantation forest $\left(1517.06 \mathrm{~km}^{2}\right)$, then shrubland $\left(327.43 \mathrm{~km}^{2}\right)$, built up $\left(158.60 \mathrm{~km}^{2}\right)$ and grassland $\left(113.17 \mathrm{~km}^{2}\right)$. The main sources of increased cropland are mainly natural forests $\left(2517.20 \mathrm{~km}^{2}\right)$ and plantation forests $\left(1165.28 \mathrm{~km}^{2}\right)$, followed by grasslands $\left(266.60 \mathrm{~km}^{2}\right)$, shrublands $\left(127.98 \mathrm{~km}^{2}\right)$, and wetlands $\left(95.46 \mathrm{~km}^{2}\right)$. From 2000 to 2017, there was strong mutual conversion between natural forests and cropland. According to the map of cropland conversion in Figure $3 b$, the areas where the cropland was converted into plantations (green areas) were mainly concentrated in the provinces of Louang Namtha, Louangphabang, and Vientiane. The area where the plantation forest was converted to cropland (yellow area) was mainly concentrated 
in the Vientiane, Bolikhamxai, and Khammouan provinces. The areas of natural forest conversion to cropland (red areas) were mainly concentrated in the provinces of Xaignabouli and Savannakhet.

Shrubland and grassland were the fastest growing areas in Laos from 2000 to 2017, increasing from $1086.80 \mathrm{~km}^{2}$ to $3563.05 \mathrm{~km}^{2}$, and $4875.23 \mathrm{~km}^{2}$ to $12,147.91 \mathrm{~km}^{2}$, respectively. According to the transfer matrix in Table 4, the increase of shrubland mainly comes from natural forests $\left(2142.62 \mathrm{~km}^{2}\right)$, followed by cropland $\left(327.43 \mathrm{~km}^{2}\right)$ and grassland $\left(199.27 \mathrm{~km}^{2}\right)$. The increase of grassland is mainly from natural forests $\left(7607.30 \mathrm{~km}^{2}\right)$, followed by cropland $\left(113.17 \mathrm{~km}^{2}\right)$ and shrubland $\left(178.09 \mathrm{~km}^{2}\right)$. Combined with the shrubland and grassland conversion map in Figure 3c, we found that the area where natural forests turn into shrubland (dark red and light red) was mainly in the northern part of Laos. The conversion of cropland to shrubland and grassland (green area) was mainly in the provinces of Champasak and Attapu, and the conversion of grassland and shrubland to cropland (yellow area) was mainly in Xiangkhoang province.

Water is a rich natural resource in Laos. In 2000, the water area of Laos was $2903.06 \mathrm{~km}^{2}$. Although the water area decreased slightly in 2005, the water area increased to some extent in 2010 and 2017, and ultimately reached $3434.70 \mathrm{~km}^{2}$. According to the land use transfer matrix in Table 4, the increased waters mainly come from natural forests $\left(451.65 \mathrm{~km}^{2}\right)$ and plantation forest $\left(224.72 \mathrm{~km}^{2}\right)$, and also a small amount from cropland $\left(35.53 \mathrm{~km}^{2}\right)$ and wetlands $\left(31.60 \mathrm{~km}^{2}\right)$. At the same time, the reduced waters are not much, and are mainly converted into wetlands $\left(61.08 \mathrm{~km}^{2}\right)$, cropland $\left(57.72 \mathrm{~km}^{2}\right)$, built up $\left(28.29 \mathrm{~km}^{2}\right)$ and aquaculture $\left(27.13 \mathrm{~km}^{2}\right)$. According to the water area conversion map in Figure $3 \mathrm{~d}$, the areas where natural forests turn into water (dark red areas) were mainly in Louangphabang and Khammouan provinces, and the plantation forest converted to water (light red areas) was mainly in Vientiane, Bolikhamxai, and Attapu provinces.

From 2000 to 2017, the wetland area in Laos generally showed a decreasing trend, from $512.16 \mathrm{~km}^{2}$ to $436.40 \mathrm{~km}^{2}$, except a small increase from 2005 to 2010 . According to the land use transfer matrix in Table 4, the reduced wetland was mainly converted into cropland $\left(95.46 \mathrm{~km}^{2}\right)$, plantation forest $\left(43.87 \mathrm{~km}^{2}\right)$, and water $\left(31.60 \mathrm{~km}^{2}\right)$. At the same time, the increase of wetlands mainly comes from water $\left(61.08 \mathrm{~km}^{2}\right)$, and a small part comes from the natural forest $\left(23.52 \mathrm{~km}^{2}\right)$, plantation forest $\left(16.31 \mathrm{~km}^{2}\right)$, and cropland $\left(15.28 \mathrm{~km}^{2}\right)$.

Built up area is also a relatively fast-growing land use type in Laos. From 2000 to 2017, the built up land area increased from $286.57 \mathrm{~km}^{2}$ to $652.53 \mathrm{~km}^{2}$, an increase of $127.70 \%$. According to the transfer matrix in Table 4, the increased built-up land was mainly from cropland $\left(158.60 \mathrm{~km}^{2}\right)$, followed by natural forest $\left(88.96 \mathrm{~km}^{2}\right)$, plantation forest $\left(56.86 \mathrm{~km}^{2}\right)$, and water $\left(28.29 \mathrm{~km}^{2}\right)$.

Mines are another rich natural resource in Laos, but it is worth noting that the area of industrial and mining changed slightly from 2000 to 2017 , but remains between $12 \mathrm{~km}^{2}$ and $12.5 \mathrm{~km}^{2}$. In addition, although the barren land and aquaculture areas of Laos accounted for a relatively small proportion of the total land area, the increases in both were relatively rapid, increasing from $21.76 \mathrm{~km}^{2}$ to $58.92 \mathrm{~km}^{2}$ and $7.85 \mathrm{~km}^{2}$ to $86.62 \mathrm{~km}^{2}$, respectively. The increase of barren land mainly came from natural forests $\left(14.92 \mathrm{~km}^{2}\right)$ and croplands $\left(11.80 \mathrm{~km}^{2}\right)$. The increase of aquaculture mainly came from natural forests $\left(28.88 \mathrm{~km}^{2}\right)$, water $\left(27.13 \mathrm{~km}^{2}\right)$, and plantation forests $\left(15.55 \mathrm{~km}^{2}\right)$.

The above analyses show that the provinces of Vientiane, Xiangkhoang, Khammouan, and Attapu are areas where land use/cover change was frequent. In general, plantation forest, cropland, built up, barren land, and aquaculture (which are significantly related to the intensity of human activities) have increased significantly. Although the area of shrubland and grassland that contributes to vegetation cover in the natural state is also increasing, it should be noted that the source of the increased area of these two land types was mainly natural forests, which leads to a large-scale reduction of natural forests, which have higher biomass and richer biodiversity. Our results show that the intensity of human activities in Laos was significantly enhanced, and the environment conducive to biodiversity is decreasing. 


\subsection{Analysis of Landscape Pattern Change}

To avoid the influence of the "salt and pepper" phenomenon of remote sensing LUCC on the landscape index, especially the index involving the number of patches, we first merged the patches fewer than two pixels with the neighboring patch that had the largest common side length, and then calculated the landscape index mentioned in Section 3. The results are shown in Figures 4 and 5.

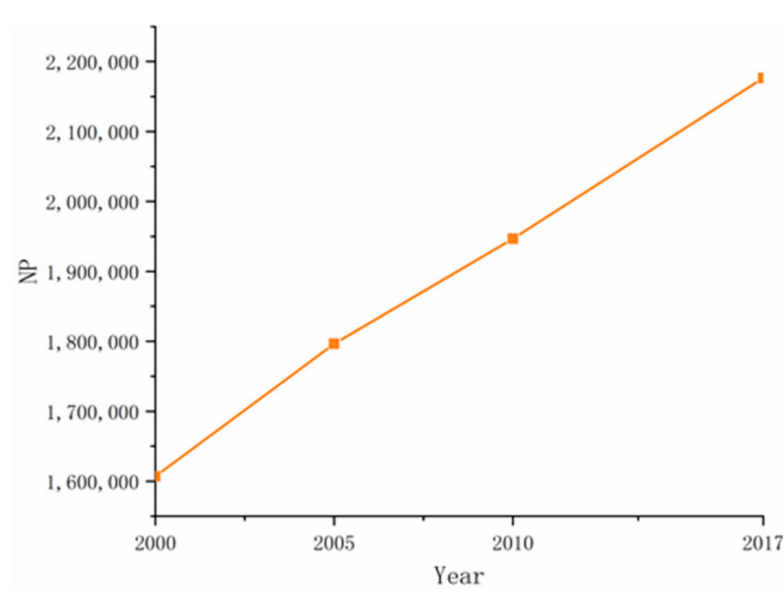

(a)

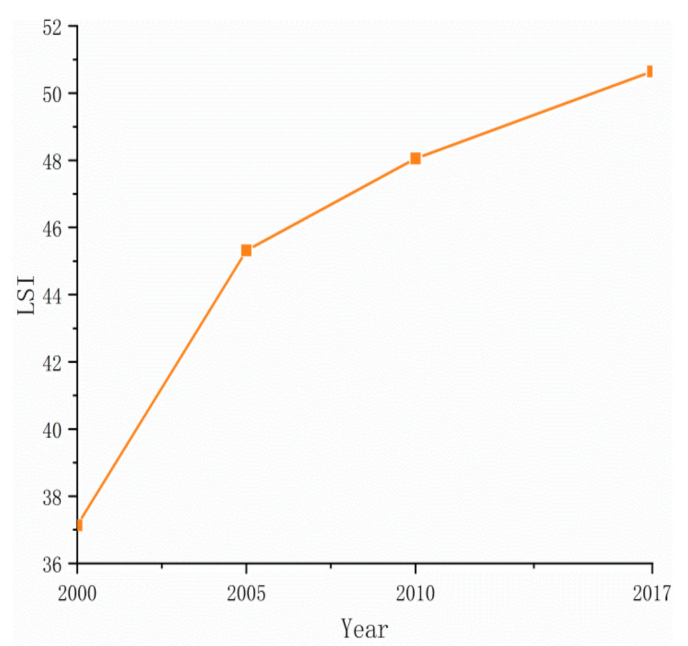

(c)

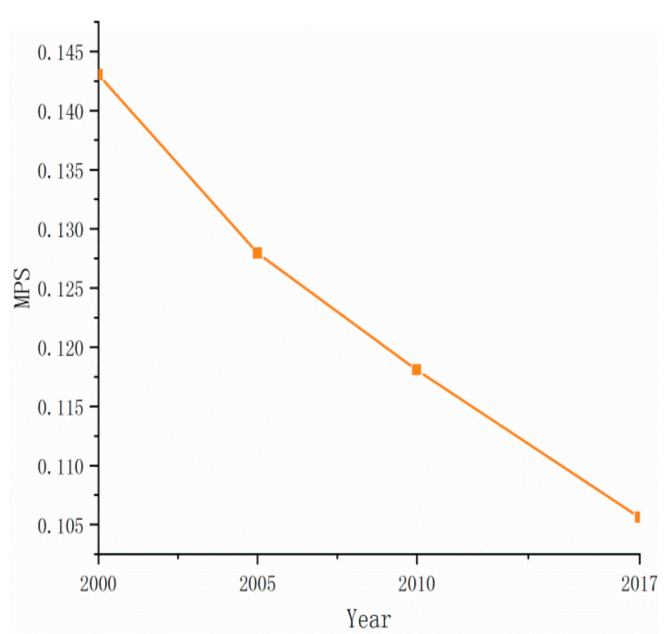

(b)

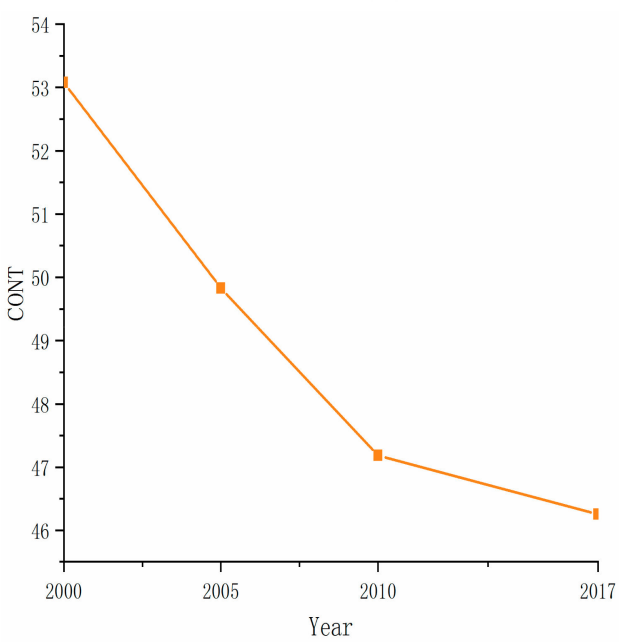

(d)

Figure 4. Landscape index results: (a) Number of patches (NP), (b) mean patch size (MPS), (c) landscape shape index (LSI), and (d) contagion index (CONT).

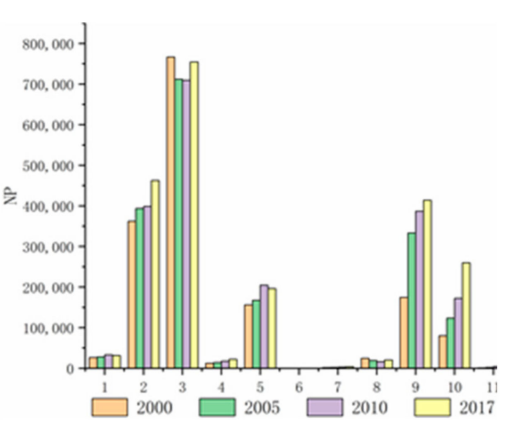

(a)

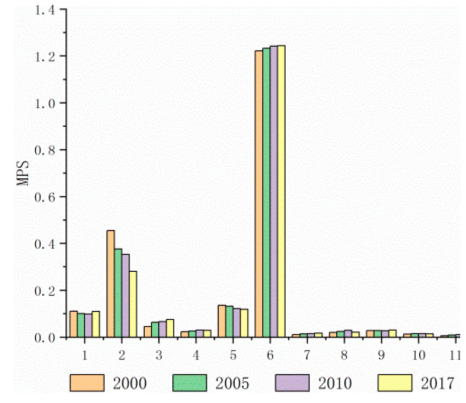

(b)

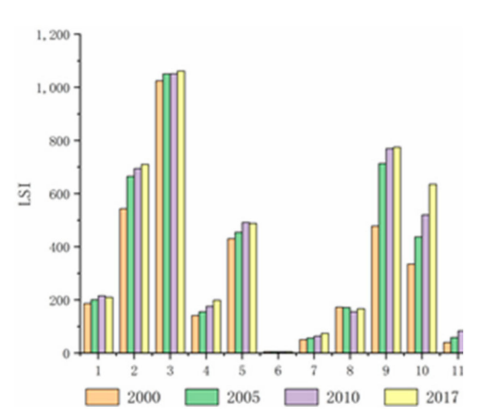

(c)

Figure 5. Class landscape index results: (a) NP; (b) MPS; (c) LSI. 
From the landscape level analyses shown in Figure 4, the NP index is gradually increasing, and the MPS index is gradually decreasing over time. Both of these trends indicate that overall human activities in Laos increased strongly, and increased the fragmentation of the landscape. According to the class level landscape index in Figure 5, natural forest, grassland, shrubland, and cropland are the major contribution to the landscape fragmentation. These land types were also the main components of LUCC in terms of area and are also the land types with relatively large change areas. For the MPS index, the decline was more obvious for natural forests. According to the principles of landscape ecology, the fragmentation and average area reduction of patches usually mean that the biodiversity of these larger patches was greatly reduced, especially for habitat-sensitive species. Combined with the land use transfer analysis in Table 4, the main reason for this situation was the conversion of natural forest to plantation forest, cropland, shrubland, and grassland.

The LSI indicator was the edge ratio per unit area, essentially. Usually, compact patches have a small proportion of margins per unit area, which helps to preserve energy, nutrients, and organisms. In contrast, loose shape depressions promote interactions between patches and the surrounding environment, especially the exchange of energy, matter, and biology. However, Figure 4 shows that the LSI index of land use at the landscape level in Laos is rising. From the change of the type level index in Figure 5, the increase was mainly natural forests, shrubs, and grasslands. This landscape pattern can easily lead to energy, nutrients, and biological conservation capacity of forest land, shrubland, and grassland. Further analysis of the land use transfer analysis in Section 4.1 shows that natural forests in this situation were mainly converted to shrublands and grasslands.

A higher CONT value indicated that a dominant patch type in the landscape forms a good connection; in contrast, lower CONT values indicate that the landscape is a dense pattern with multiple classes, and the degree of fragmentation of the landscape is higher. According to the results of Figure 4, we found that the CONT index of Laos has been declining from 2000 to 2017. According to the fact that natural forests dominated the land cover in Section 4.1, the connectivity of natural forests declined.

Based on the analysis of the four landscape indices above, the land use patterns in Laos were basically increasing towards heterogeneity and increasing the degree of patch fragmentation both at the land class and landscape levels. According to the principles of landscape ecology, these trends are not conducive to the biodiversity environment and the storage capacity of energy, nutrients, and organisms in the ecological environment. Combined with the analysis of the land use transfer matrix, it is evident that the main cause of this trend was the degradation of natural forests, especially the conversion of forest land to grassland, shrubland, and cropland.

\subsection{Topographic Analysis of Changed Area}

According to the analysis in Sections 4.1 and 4.2, the changes in Laos were mainly concentrated in natural forests. Hence, we carried out elevation and slope grading statistics of natural forest conversion, including water, plantation forest, cropland, grassland, and shrubland (see Figure 6). According to Figure 6a, the area where natural forests are transformed into plantation forest is mainly concentrated between elevation levels 1 and 2, which means below $1000 \mathrm{~m}$. Similar patterns occurred in the transformation of natural forest to water, cropland, and shrubland. However, there was a difference in the transformation of natural forest to grassland: it was mainly distributed in grades 2 and 3 , especially grades 3 of $1000-1500 \mathrm{~m}$. From the perspective of the slope grades distribution (Figure $6 \mathrm{~b}$ ), there was a big difference. For natural forests transformed into plantation forests and grasslands, the changing areas were mainly distributed in the first three grades, that is, below 35 degrees, and the most was between 10-35 degrees. The transformation of natural forests to water bodies was fairly equally distributed between grades 1,2, and 3, and the transformation of natural forests to shrublands was mainly distributed in grades 1 and 3 . 


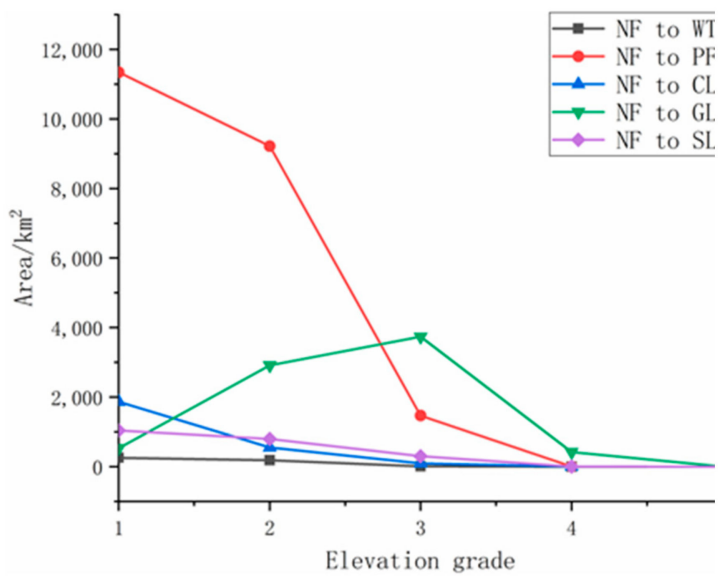

(a)

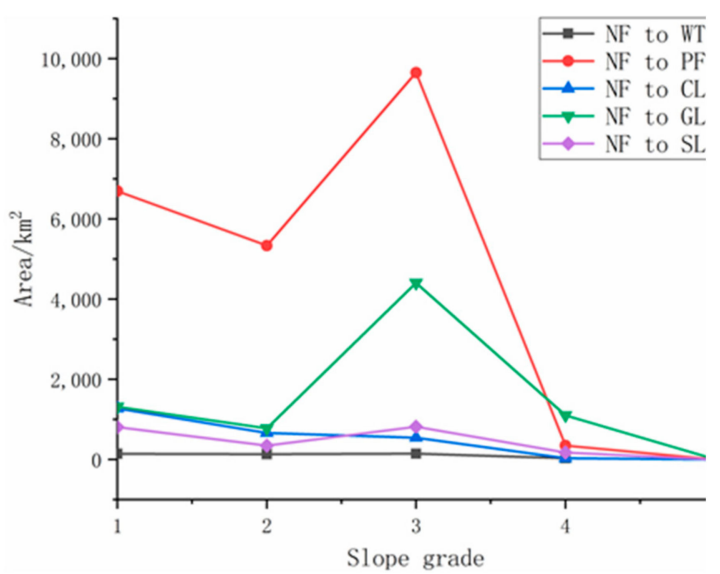

(b)

Figure 6. Topographic statistics of natural forest land change: (a) elevation grade distribution; and (b) slope grade distribution.

Since cropland was a land use type with stronger human activity than other covered land use types, we also counted the elevation and slope of the area changed to cropland (see Figure 7), including water, plantation forest, wetland, grassland, shrubland. Figure 7a shows that these areas of variation are mainly concentrated below an elevation of $500 \mathrm{~m}$. For grassland and shrubland, distribution between 1000-1500 m was higher. From the slope point of view (Figure 7b), most of the water and wetlands converted to cropland were within 3 degrees of the slope. Although the plantation forests, grasslands, and shrublands converted to cropland were mainly distributed within 3 degrees, there are still many areas distributed between 3 and 35 degrees, especially for grassland and shrubland, as these areas are more than $3-10$ degrees in the 10-35 area.

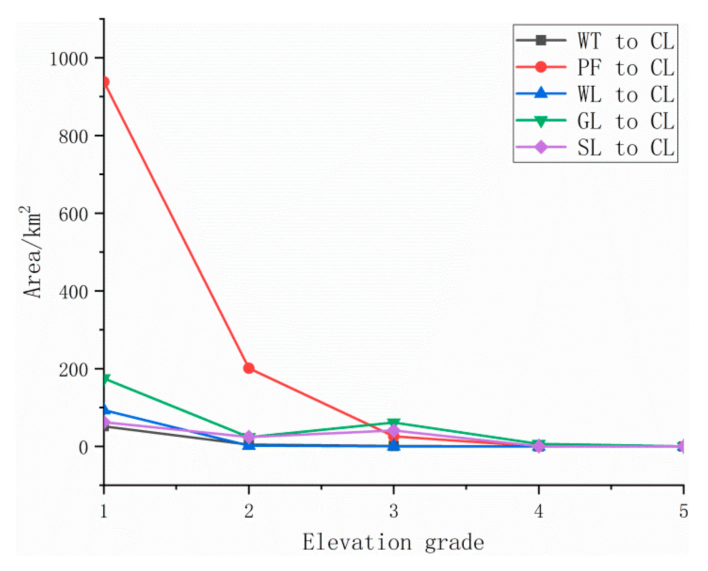

(a)

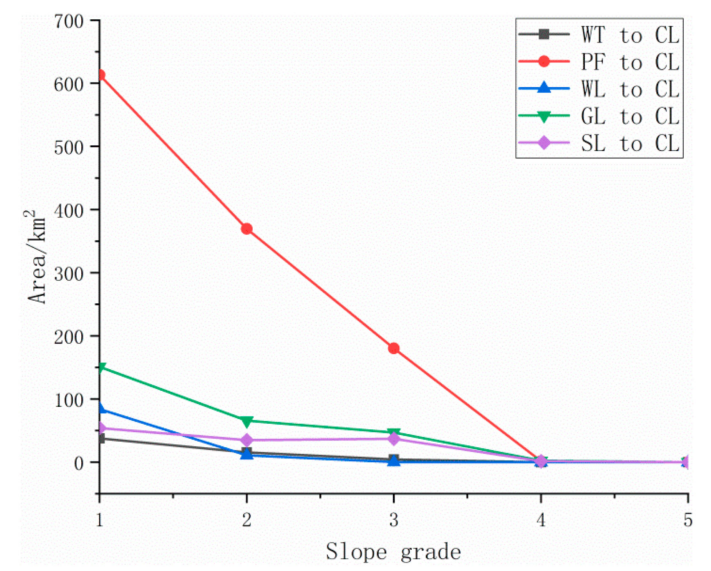

(b)

Figure 7. Topographic statistical of cropland: (a) elevation grade and (b) slope grade.

The above results show that the low elevation area was still the hot spot for the changing areas. For example, the reduction of natural forests and cropland, but it should be noted that the reduction of natural forests had also begun to expand to high elevation areas. From the perspective of slope, the area converted to cropland was still concentrated in the low slope area below 10 degrees. However, most of the transform from natural forests were concentrated in the range of 10 to 35 degrees, especially the natural forests converted to plantation forests, grasslands, and shrublands. 


\section{Discussion}

According to the analysis in Section 4, natural forests are the main land type in Laos and its change is also the core factor that influences the entire ecological environment of Laos. Using a transfer matrix analysis, we found that natural forests were greatly transformed into plantation forests, shrublands, and grasslands, which caused a continuous reduction of natural forest resources. Landscape pattern analysis showed that the degradation of natural forests not only led to the reduction of resources, but also led to the fragmentation of these ecological patches. The topographic analysis shows that the degradation of natural forests began spreading to high-altitude areas, and many of degradation areas are concentrated at the slightly higher slopes of 10-35 degrees. Combined with Laos's forest import and export data (Figure 8), it can also be seen that the export value of forest land has increased significantly during this period, which is consistent with the decline of natural forests and the increase of plantation forests. This shows that the massive export of forest resources was a major driving force for forest degradation. Undeniably, forest land resources are a renewable dynamic resource. Under the conditions of favorable climate in Laos, grasslands will grow into the forest again through the process of shrub-forest land conversion, but it should be noted that this growth has a cycle. It usually takes 20 to 30 years or even longer to return to the natural forest with the original ecological function. However, the current rate of decline in natural forests was significantly higher than this rate of recovery, resulting in a direct decline in the proportion of natural forests to the overall land area from $71 \%$ in 2000 to $56 \%$ in 2017. In addition, the reduction of natural forests also brings about the fragmentation of ecological patches. Fragmentation poses a potential threat to the diversity of organisms, and even leads to a decline in the storage capacity of ecosystem energy, nutrients, and organisms $[13,25]$. Of the area that is changing, we found that especially in the high slope areas of natural forests, shrublands and grasslands, there were increased risks to soil quality and even increased potential disaster risks, such as floods and landslides.

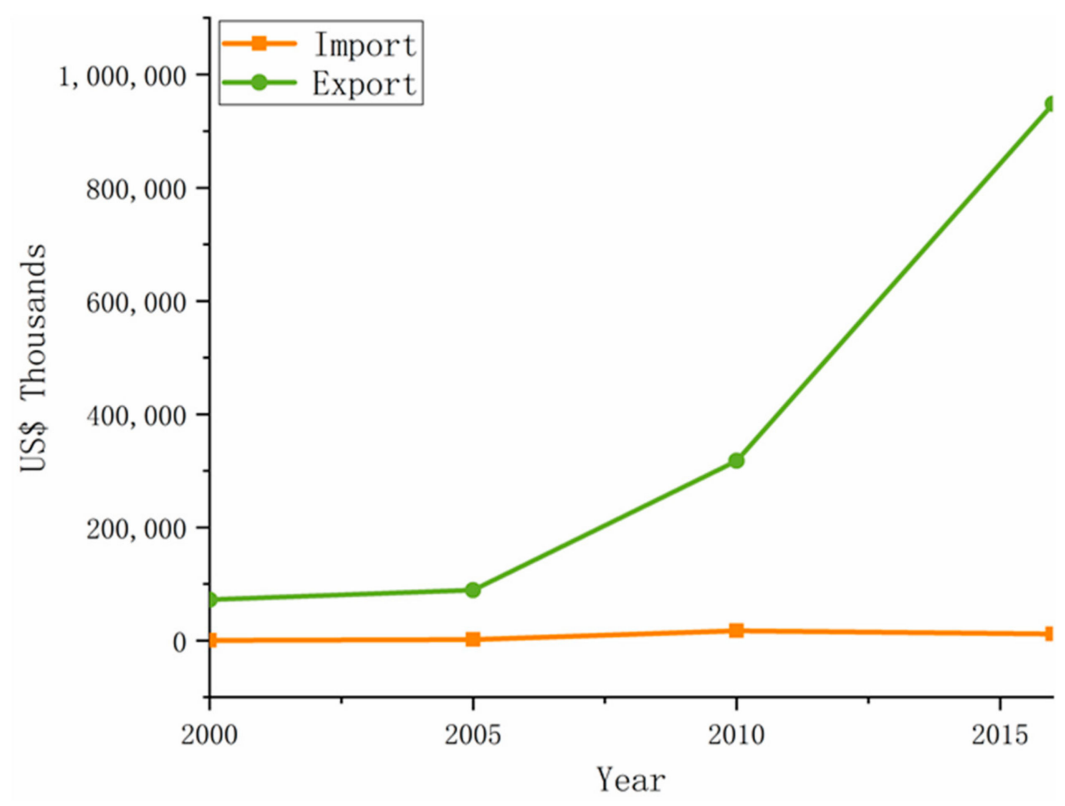

Figure 8. Imports and exports of forest products in Laos (Source: [32]).

According to the population data (Figure 9a), the human population of Laos continues to increase. Compared with 2000, the total population of Laos increased by $27.31 \%$ in 2015, of which the urban population increased by $128.89 \%$ and the rural population decreased by $1.62 \%$. Although cropland and built up lands are also increased during this period, the increase ratio is obviously inconsistent with the increase of population. From the perspective of food supply, if the import and export data are not considered, the increased population should require an equal increase in the proportion of the 
supply of agricultural products. According to the data in Section 4.1, compared with 2000, cropland in Laos increased by only $9.66 \%$ in 2017. From the data on the import and export of agricultural products (Figure 9b), the export of agricultural products in Laos gradually increased after 2005; at the same time, the import of agricultural products in Laos also rose sharply. In 2013, imports were more than three times that of exports. This is significantly different from the advantages of conventional developing countries in increasing foreign trade by exporting their own agricultural products. Another possible reason is that the area of aquaculture in Laos is increasing. According to the analysis in Section 4.1, the aquaculture area increased from $7.85 \mathrm{~km}^{2}$ in 2000 to $86.62 \mathrm{~km}^{2}$ in 2017 , which can greatly increase the supply of food [52]. The fact that the area of cropland increases but the rural population is decreasing, shows that Laos' food labor productivity has increased significantly in the context of economic globalization. The built up land area increased from 2000 to 2017 by $129.05 \%$, which was more than four times the increase in the total population $(27.31 \%)$. However, it is very close to the urban population increase ratio of $128.89 \%$. This indicates that the urban population increase is a major driver of the increase in built up area. The change in industrial structures during this period (Figure 9c) shows that the proportion of industrial and service output has continued to increase from 2000 to 2015. This can be regarded as evidence that the added built up area was mainly used for industry and service.

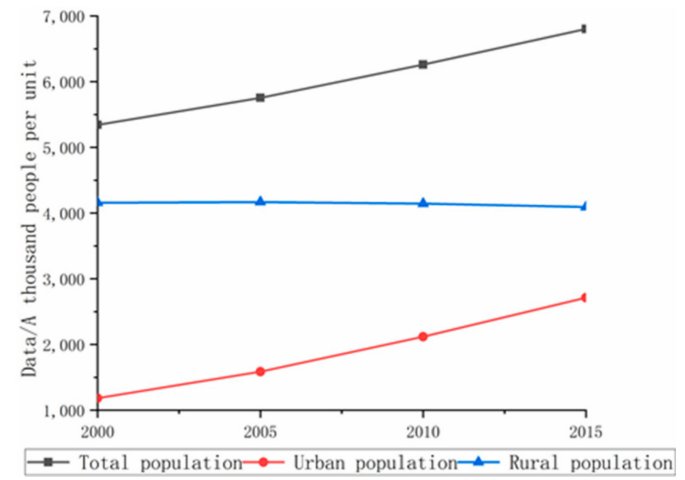

(a)

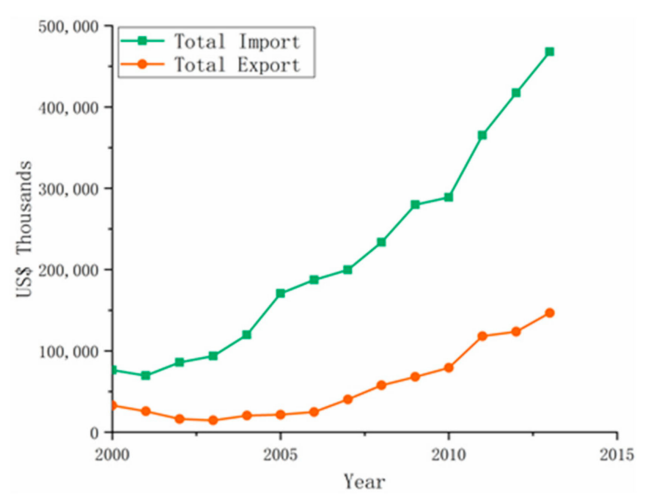

(b)

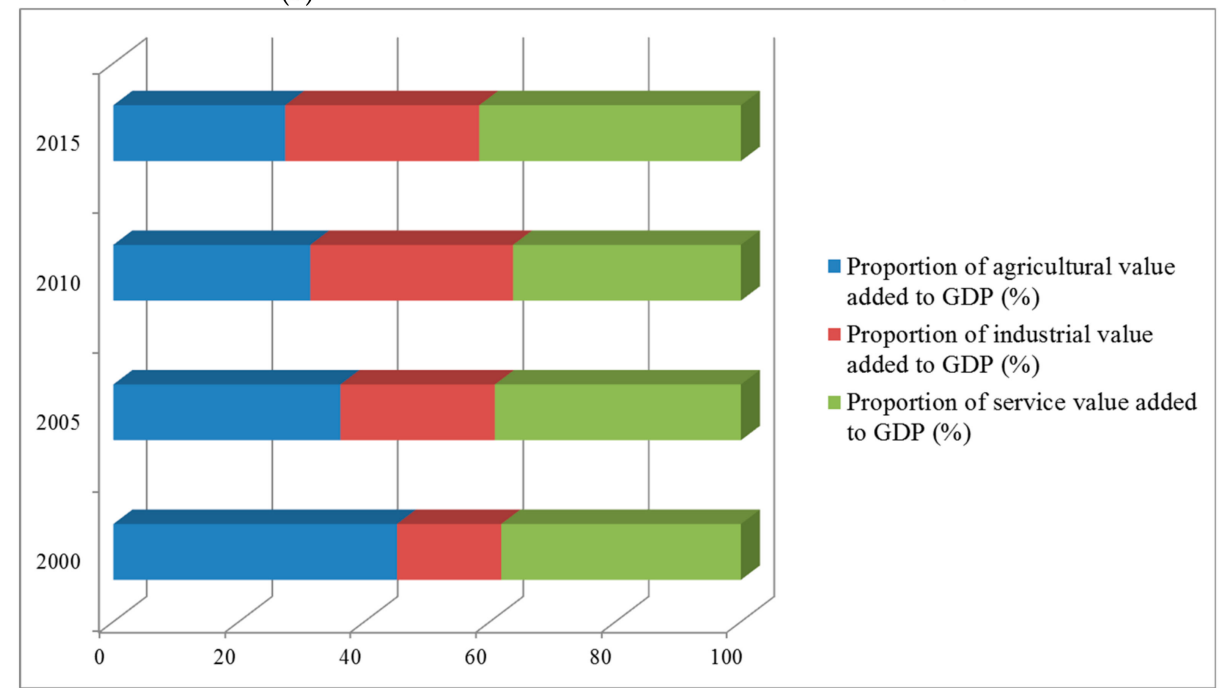

(c)

Figure 9. Population, import and export volume and industrial structure of Laos: (a) urban and rural population in Laos, (b) imports and exports of agricultural products in Laos, and (c) industrial structure in Laos. (Source: [32]). 
Laos is rich in water resources and is the country with the most abundant water resources in Southeast Asia. The Mekong River, the sixth largest river in the world, runs from north to south across the country. Laos's rich water resources benefit from its superior climatic conditions, namely tropical and subtropical monsoon climates, with a five-month rainy season that brings nearly $2000 \mathrm{~mm}$ of precipitation per year. At the same time, the terrain of a high-elevation north and a low-elevation south makes Laos rich in hydrodynamic energy [30]. Therefore, Laos has made hydropower generation a strategic implementation of the development of the economy; hydropower has also made a great contribution to the economic development of Laos (Figure 10). Statistical analysis has shown that power generation in Laos has remained at a low level of stability until 2009, after which power generation rose sharply. It is noteworthy that before 2014, Laos' electricity generation was basically composed of hydropower. Although other forms of power generation have begun to appear after 2014, hydropower still occupies the highest rank position. Comparing Laos's electricity production and export data, we also found that only a small portion of the electricity produced by Laos is used for its own consumption, but rather most was used for export. Taking 2016 as an example, the total power generation was 29.74 billion kilowatt-hours, but 23.79 billion kilowatt-hours of electricity was used for export, accounting for up to $80 \%$ of the generated total. Behind the increase in hydropower was the construction of an increasing number of hydroelectric dams. These activities will inevitably lead to an increase in the water area. From the analysis results in Section 4.1, the water area of Laos increased from $2903.06 \mathrm{~km}^{2}$ in 2000 to $3343.70 \mathrm{~km}^{2}$ in 2017. The increase in the water area also brought about an increase in the wetland area. The wetland area in Laos increased from $512.16 \mathrm{~km}^{2}$ in 2000 to $436.40 \mathrm{~km}^{2}$ in 2017. From the perspective of ecosystem function, the increase in water and wetland areas is advantageous [53]. However, the premise of this increase is that Laos has established a dam to intercept water bodies, especially the water bodies in the Mekong River Basin. This interception will inevitably have an important impact on the ecosystems of the lower Mekong River located in neighboring countries. Potential impacts include saltwater intrusion into the mouth of the Mekong River in Vietnam and damage to irrigation, shipping, and fisheries in other downstream countries. These potential impacts may exacerbate economic and social growth, ecological security, and the lives of residents in downstream countries [54,55].

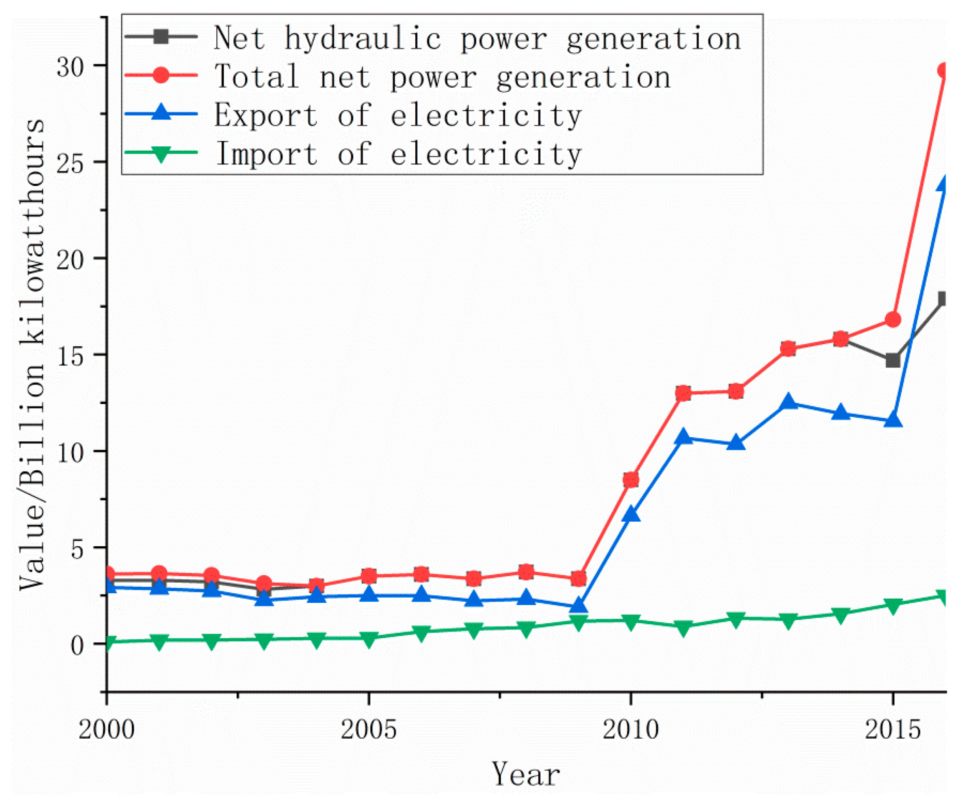

Figure 10. Statistics on electricity production and imports and exports in Laos (Source: [32]).

Mines are also a rich resource in Laos [29]. Judging from the mineral exports of Laos (Figure 11), there is an increasing trend in mineral exports, especially from 2005 to 2010 . With the decline in the 
price of gold and copper on the international market, the mineral export volume of Laos declined in 2017. But its volume is still maintained above $\$ 800 \mathrm{M}$, making it 172.6 times higher than the value in 2000. However, according to the statistics of land use/coverage data used in this paper, the increase in the surface area of the mining area was very limited, from $12 \mathrm{~km}^{2}$ in 2000 to $12.5 \mathrm{~km}^{2}$ in 2017 . On the one hand, the emergence of this situation may be that Laos has remained cautious in the development of mining areas, and has not carried out large-scale expansion; on the other hand, it may be that the data resolution used is still insufficient, and a large number of small mines in the mapping process neglected, resulting in fewer area statistics.

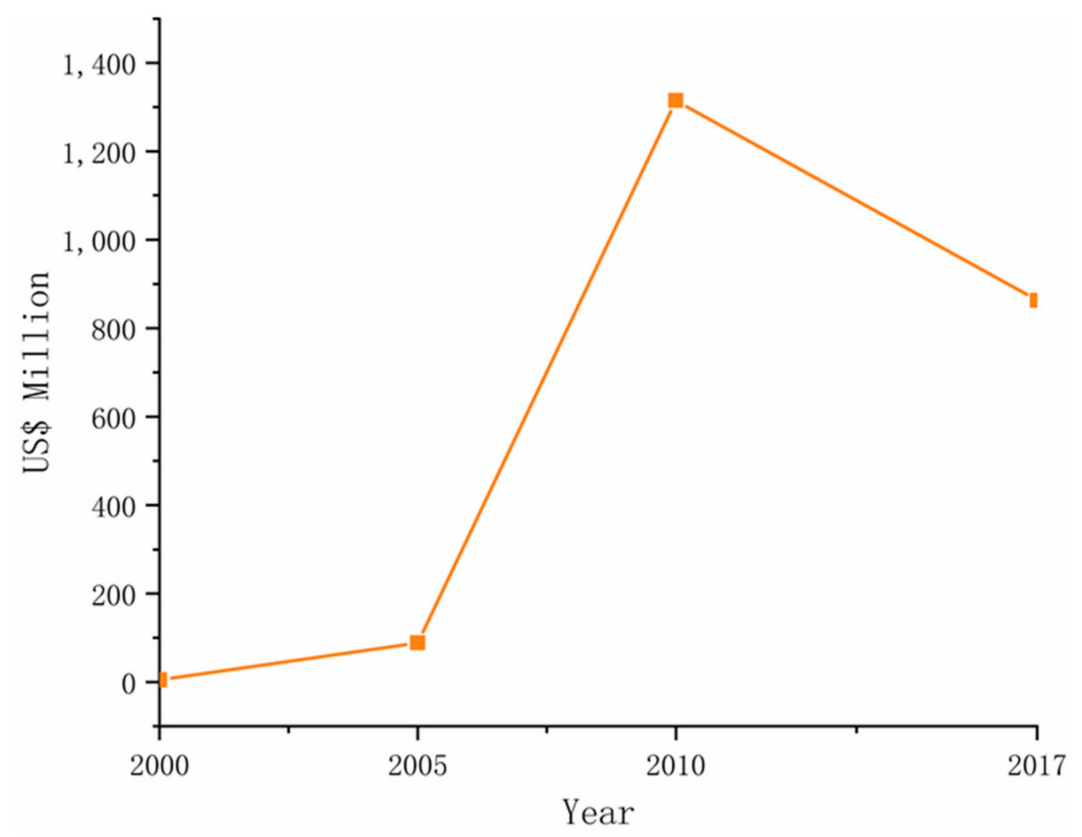

Figure 11. Mineral exports from Laos (Source: [32]).

\section{Conclusions}

We analyzed the land use/cover of Laos by transfer matrix, landscape pattern, and topographic analysis, and also coupled that with the economic statistics for the same period. We found that since the millennium, Laos's land use/cover has undergone dramatic changes driven by economic globalization. These changes are mainly reflected in the conversion of natural forest land to plantation forest, and the degradation of natural forest to shrubland and grassland. In addition, we found high fragmentation of natural forest patches and a change in the regional distribution of forests at high altitudes and large slopes, which was closely related to the large-scale export of wood products. At the same time, the types of land use closely related to human activities such as cropland, built up, aquaculture, and barren land were also growing substantially, which is related to the economic development of Laos and the increasing proportion of the secondary and tertiary industries. In addition, due to the development of hydropower resources, the area of water and wetlands also increased, and hydropower exports were a major driver. Although Laos is an inland developing country and its transportation facilities are not well developed, according to our land cover and related economic statistics, the ecological environment in Laos was still affected by economic globalization. However, due to regional characteristics, Laos presents a unique version of the development of globalization, such as increased hydropower resources.

If properly managed, the forest resources will remain a renewable resource that will become a substantial advantage for Laos in terms of economic globalization. Although the area of forest land in Laos has not decreased overall since 2000, the proportion of natural forests with high ecological value has decreased drastically, falling from $71.40 \%$ of the country's land area to $56.29 \%$. Moreover, these reduced areas also lead to patch fragmentation, and to high altitude, large slope expansions, which 
bring greater potential risks to the biodiversity and for soil degradation. Accordingly, the government should make a reasonable restrictive protection policy to stop the further reduction of natural forest resources. Otherwise, the barren land that seems to occupy a small proportion in current time will be incrementally expanded, continuously encroaching on the resource-rich natural forest lands, and leading to a deterioration of the ecological environment.

In general, water area increases are beneficial, and enhance the function of the ecosystem while also contributing to the development of the aquaculture industry, concurrently reducing the pressure of food demand. The development of hydropower in Laos has increased the area of water and wetlands in the country. If only from the perspective of Laos, this development is not only sustainable, but also environmentally friendly. However, due to the inland nature of Laos and its borders with neighboring countries, the interception of water for electric power will inevitably affect the ecosystems in downstream countries that depend on these resources. But it still needs further study to verify whether the impact on the downstream countries is serious.

Author Contributions: Conceptualization, Z.W. and X.Y. and D.G.; methodology, Z.W. and J.W.; software, J.W.; validation, Z.W. and D.G. and L.S.; formal analysis, J.W. and J.K.; investigation, F.Y. and Y.L.; resources, J.W. and D.G.; data curation, B.L. and J.K.; writing—original draft preparation, J.W.; writing-review and editing, J.W. and Z.W. and L.S.; supervision, L.S and X.Y.; project administration, X.Y.; funding acquisition, X.Y.

Funding: This research was funded by the CAS Earth Big Data Science Project of China, Grant No. XDA19060303; the National Science Foundation of China, Grant Nos. 41671436 and 41421001; the Innovation Project of LREIS, Grant No. O88RAA01YA; the MOE (Ministry of Education in China) Project of Humanities and Social Sciences, Grant No. 19YJCZH036 and the CAS Key Laboratory of Regional Sustainable Development Modeling, Grant No. KF2018-02.

Acknowledgments: We are grateful to the anonymous reviewers for their valuable comments.

Conflicts of Interest: The authors declare no conflict of interest.

\section{References}

1. Polasky, S.; Nelson, E.; Camm, J.; Csuti, B.; Fackler, P.; Lonsdorf, E.; Montgomery, C.; White, D.; Arthur, J.; Garber-Yonts, B.; et al. Where to put things? Spatial land management to sustain biodiversity and economic returns. Biol. Conserv. 2008, 141, 1505-1524. [CrossRef]

2. Ge, D.Z.; Long, H.L.; Zhang, Y.G.; Ma, L.; Li, T.T. Farmland transition and its influences on grain production in China. Land Use Policy 2018, 70, 94-105. [CrossRef]

3. Ge, D.; Wang, Z.; Tu, S.; Long, H.; Yan, H.; Sun, D.; Qiao, W. Coupling analysis of greenhouse-led farmland transition and rural transformation development in China's traditional farming area: A case of Qingzhou City. Land Use Policy 2019, 86, 113-125. [CrossRef]

4. Nahuelhual, L.; Carmona, A.; Lozada, P.; Jaramillo, A.; Aguayo, M. Mapping recreation and ecotourism as a cultural ecosystem service: An application at the local level in Southern Chile. Appl. Geogr. 2013, 40, 71-82. [CrossRef]

5. Balthazar, V.; Vanacker, V.; Molina, A.; Lambin, E.F. Impacts of forest cover change on ecosystem services in high Andean mountains. Ecol. Indic. 2015, 48, 63-75. [CrossRef]

6. Cabral, A.I.R.; Costa, F.L. Land cover changes and landscape pattern dynamics in Senegal and Guinea Bissau borderland. Appl. Geogr. 2017, 82, 115-128. [CrossRef]

7. Hao, R.F.; Yu, D.Y.; Liu, Y.P.; Liu, Y.; Qiao, J.M.; Wang, X.; Du, J.S. Impacts of changes in climate and landscape pattern on ecosystem services. Sci. Total Environ. 2017, 579, 718-728. [CrossRef]

8. Arowolo, A.O.; Deng, X.Z.; Olatunji, O.A.; Obayelu, A.E. Assessing changes in the value of ecosystem services in response to land-use/land-cover dynamics in Nigeria. Sci. Total Environ. 2018, 636, 597-609. [CrossRef]

9. Polasky, S.; Nelson, E.; Pennington, D.; Johnson, K.A. The Impact of Land-Use Change on Ecosystem Services, Biodiversity and Returns to Landowners: A Case Study in the State of Minnesota. Environ. Resour. Econ. 2011, 48, 219-242. [CrossRef]

10. Kellenberg, D. Trading wastes. J. Environ. Econ. Manag. 2012, 64, 68-87. [CrossRef]

11. Furumo, P.R.; Aide, T.M. Characterizing commercial oil palm expansion in Latin America: Land use change and trade. Environ. Res. Lett. 2017, 12, 024008. [CrossRef] 
12. Chen, Q.; Li, Y.C.; Liu, C.X.; Yang, Y.N.; Wu, J.; Li, M.Y. Spatio-Temporal Variation in Mountainous Landscape Changes: A Case Study of Shizhu County. Sustainability 2019, 11, 2131. [CrossRef]

13. Dadashpoor, H.; Azizi, P.; Moghadasi, M. Land use change, urbanization, and change in landscape pattern in a metropolitan area. Sci. Total Environ. 2019, 655, 707-719. [CrossRef]

14. Krajewski, P. Monitoring of Landscape Transformations within Landscape Parks in Poland in the 21st Century. Sustainability 2019, 11, 2410. [CrossRef]

15. Li, Z.; Liu, W.Z.; Zhang, X.C.; Zheng, F.L. Impacts of land use change and climate variability on hydrology in an agricultural catchment on the Loess Plateau of China. J. Hydrol. 2009, 377, 35-42. [CrossRef]

16. Veijalainen, N.; Dubrovin, T.; Marttunen, M.; Vehvilainen, B. Climate Change Impacts on Water Resources and Lake Regulation in the Vuoksi Watershed in Finland. Water Resour. Manag. 2010, 24, 3437-3459. [CrossRef]

17. Wenbin, W.U.; Peng, Y.; Huajun, T.; Luca, O.; Ryosuke, S. Regional Variability of Effects of Land Use System on Soil Properties. Sci. Agric. Sin. 2007, 40, 1697-1702.

18. Zhang, S.H.; Li, Y.Q.; Fan, W.W.; Yi, Y.J. Impacts of Rainfall, Soil Type, and Land- Use Change on Soil Erosion in the Liusha River Watershed. J. Hydrol. Eng. 2017, 22, 11. [CrossRef]

19. Serpa, D.; Nunes, J.P.; Keizer, J.J.; Abrantes, N. Impacts of climate and land use changes on the water quality of a small Mediterranean catchment with intensive viticulture. Environ. Pollut. 2017, 224, 454-465. [CrossRef]

20. Meffert, P.J.; Dziock, F. The influence of urbanisation on diversity and trait composition of birds. Landsc. Ecol. 2013, 28, 943-957. [CrossRef]

21. Seppelt, R.; Lautenbach, S.; Volk, M. Identifying trade-offs between ecosystem services, land use, and biodiversity: A plea for combining scenario analysis and optimization on different spatial scales. Curr. Opin. Environ. Sustain. 2013, 5, 458-463. [CrossRef]

22. Wang, X.C.; Dong, X.B.; Liu, H.M.; Wei, H.J.; Fan, W.G.; Lu, N.C.; Xu, Z.H.; Ren, J.H.; Xing, K.X. Linking land use change, ecosystem services and human well-being: A case study of the Manas River Basin of Xinjiang, China. Ecosyst. Serv. 2017, 27, 113-123. [CrossRef]

23. Hostert, P.; Kuemmerle, T.; Prishchepov, A.; Sieber, A.; Lambin, E.F.; Radeloff, V.C. Rapid land use change after socio-economic disturbances: The collapse of the Soviet Union versus Chernobyl. Environ. Res. Lett. 2011, 6, 045201. [CrossRef]

24. Rutten, M.; van Dijk, M.; van Rooij, W.; Hilderink, H. Land Use Dynamics, Climate Change, and Food Security in Vietnam: A Global-to-local Modeling Approach. World Dev. 2014, 59, 29-46. [CrossRef]

25. Yamamoto, Y.; Shigetomi, Y.; Ishimura, Y.; Hattori, M. Forest change and agricultural productivity: Evidence from Indonesia. World Dev. 2019, 114, 196-207. [CrossRef]

26. Paudyal, K.; Baral, H.; Bhandari, S.P.; Bhandari, A.; Keenan, R.J. Spatial assessment of the impact of land use and land cover change on supply of ecosystem services in Phewa watershed, Nepal. Ecosyst. Serv. 2019, 36, 100895. [CrossRef]

27. Meyfroidt, P.; Lambin, E.F.; Erb, K.H.; Hertel, T.W. Globalization of land use: Distant drivers of land change and geographic displacement of land use. Curr. Opin. Environ. Sustain. 2013, 5, 438-444. [CrossRef]

28. Destek, M.A. Investigation on the role of economic, social, and political globalization on environment: Evidence from CEECs. Environ. Sci. Pollut. Res. 2019, 1-14. [CrossRef]

29. Vilaihong, M.; UN. Status of Geological Mapping and Mineral Resource Assessment and Development in the Lao People's Democratic Republic; Economic and Social Commission for Asia and the Pacific, United Nations: Bangkok, Thailand, 2000; Volume 11, pp. 163-209.

30. Watcharejyothin, M.; Shrestha, R.M. Effects of cross-border power trade between Laos and Thailand: Energy security and environmental implications. Energy Policy 2009, 37, 1782-1792. [CrossRef]

31. Xiong, Y.S. Opportunities and Challenges Laos Facing after Joining into WTO. Around Southeast Asia 2013, 8 , 41-45.

32. World Bank. World Bank Open Data. Available online: https://data.worldbank.org.cn (accessed on 15 February 2019).

33. Kokmila, K.; Lee, W.K.; Badarch, O.; Kim, S.R.; Choi, S.; Park, S. Mapping Forest Functions Using GIS at Plateau Area, Laos. For. Sci. Technol. 2009, 5, 57-61. [CrossRef]

34. Hewanma, Z.; Wu, C. Analysis of Forest cover change and its driving Force in Laos. Geogr. Res. 2009, 28, 391-401.

35. Fujisaka, S. A diagnostic survey of shifting cultivation in Northern Laos-Targeting research to improve sustainability and productivity. Agrofor. Syst. 1991, 13, 95-109. [CrossRef] 
36. Sandewall, M.; Ohlsson, B.; Sawathvong, S. Assessment of Historical Land-Use Changes for Purposes of Strategic Planning-A Case Study in Laos. Ambio-J. Hum. Environ. 2001, 30, 55-61. [CrossRef]

37. Grekousis, G.; Mountrakis, G.; Kavouras, M. An overview of 21 global and 43 regional land-cover mapping products. Int. J. Remote Sens. 2015, 36, 5309-5335. [CrossRef]

38. Hansen, M.C.; Reed, B. A comparison of the IGBP DISCover and University of Maryland $1 \mathrm{~km}$ global land cover products. Int. J. Remote Sens. 2000, 21, 1365-1373. [CrossRef]

39. Bartholome, E.; Belward, A.S. GLC2000: A new approach to global land cover mapping from Earth observation data. Int. J. Remote Sens. 2005, 26, 1959-1977. [CrossRef]

40. Friedl, M.A.; Sulla-Menashe, D.; Tan, B.; Schneider, A.; Ramankutty, N.; Sibley, A.; Huang, X.M. MODIS Collection 5 global land cover: Algorithm refinements and characterization of new datasets. Remote Sens. Environ. 2010, 114, 168-182. [CrossRef]

41. Arino, O.; Gross, D.; Ranera, F.; Leroy, M.; Bicheron, P.; Brockman, C.; Defourny, P.; Vancutsem, C.; Achard, F.; Durieux, L.; et al. GlobCover ESA service for Global land cover from MERIS. In Proceedings of the 2007 IEEE International Geoscience and Remote Sensing Symposium, Barcelona, Spain, 23-27 July 2007; Volume 1-12, pp. 2412-2415.

42. Defourny, P.; Schouten, L.; Bartalev, S.; Bontemps, S.; Caccetta, P.; Hazeu, G.W.; Bella, C.D.; Gerard, B.; Giri, C.; Gonf, V.; et al. Accuracy assessment of a $300 \mathrm{~m}$ global land cover map: The GlobCover experience. New Libr. World 2009, 112, 236-247.

43. Chen, J.; Chen, J.; Liao, A.P.; Cao, X.; Chen, L.J.; Chen, X.H.; He, C.Y.; Han, G.; Peng, S.; Lu, M.; et al. Global land cover mapping at $30 \mathrm{~m}$ resolution: A POK-based operational approach. ISPRS J. Photogramm. Remote Sens. 2015, 103, 7-27. [CrossRef]

44. Gong, P.; Wang, J.; Yu, L.; Zhao, Y.C.; Zhao, Y.Y.; Liang, L.; Niu, Z.G.; Huang, X.M.; Fu, H.H.; Liu, S.; et al. Finer resolution observation and monitoring of global land cover: First mapping results with Landsat TM and ETM+ data. Int. J. Remote Sens. 2013, 34, 2607-2654. [CrossRef]

45. Lu, C.; Yang, X.M.; Wang, Z.H.; Li, Z. Using multi-level fusion of local features for land-use scene classification with high spatial resolution images in urban coastal zones. Int. J. Appl. Earth Obs. Geoinf. 2018, 70, 1-12. [CrossRef]

46. Wang, Z.H.; Lu, C.; Yang, X.M. Exponentially sampling scale parameters for the efficient segmentation of remote-sensing images. Int. J. Remote Sens. 2018, 39, 1628-1654. [CrossRef]

47. Wang, Z.; Yang, X.; Lu, C.; Yang, F. A scale self-adapting segmentation approach and knowledge transfer for automatically updating land use/cover change databases using high spatial resolution images. Int. J. Appl. Earth Obs. Geoinf. 2018, 69, 88-98. [CrossRef]

48. Kang, J.; Sui, L.; Yang, X.; Wang, Z.; Huang, C. Spatial Pattern Consistency among Different Remote-Sensing Land Cover Datasets: A Case Study in Northern Laos. ISPRS Int. J. Geo-Inf. 2019, 8, 201. [CrossRef]

49. Liu, F.; Qin, T.L.; Girma, A.; Wang, H.; Weng, B.S.; Yu, Z.L.; Wang, Z.L. Dynamics of Land-Use and Vegetation Change Using NDVI and Transfer Matrix: A Case Study of the Huaihe River Basin. Pol. J. Environ. Stud. 2019, 28, 213-223. [CrossRef]

50. Wu, J. Landscape Ecology Pattern, Process, Scale and Hierarchy; Higher Education Press: Beijing, China, 2007.

51. Mao, P. Land Use Change and Its Comprehensive Ecological Effect of Savannakhet in Lao PDR; WuHan University: Wuhan, China, 2017.

52. Ottinger, M.; Clauss, K.; Kuenzer, C. Aquaculture: Relevance, distribution, impacts and spatial assessments-A review. Ocean Coast. Manag. 2016, 119, 244-266. [CrossRef]

53. Steele, M.K.; Heffernan, J.B. Morphological characteristics of urban water bodies: Mechanisms of change and implications for ecosystem function. Ecol. Appl. 2014, 24, 1070-1084. [CrossRef]

54. Zhong, C.; Hao, L. Dilemmas of hydropower development in Laos. Energy Sources Part B 2017, 12, 570-575. [CrossRef]

55. Yuan, L.; He, W.J.; Liao, Z.Y.; Degefu, D.M.; An, M.; Zhang, Z.F.; Wu, X. Allocating Water in the Mekong River Basin during the Dry Season. Water 2019, 11, 17. [CrossRef]

(C) 2019 by the authors. Licensee MDPI, Basel, Switzerland. This article is an open access article distributed under the terms and conditions of the Creative Commons Attribution (CC BY) license (http://creativecommons.org/licenses/by/4.0/). 